\title{
MANAGEMENT OF THE INTERNATIONAL DISTRIBUTION CHANNELS IN THE SMES INTERNATIONAL BUSINESS STRATEGY
}

\author{
Bojan Vapa* \\ Vojvodinaput-Bačkaput \\ Novi Sad, Republic of Serbia \\ Jelena Vapa Tankosić \\ Faculty of Economics and Engineering Management \\ Novi Sad, Republic of Serbia
}

\begin{abstract}
Companies implementing a strategy based on entering foreign markets have to make a decision on choosing an adequate international distribution channels. Well implemented international distribution system in export-oriented companies can help them improve their competitiveness and better position their products in foreign markets. It is for this reason that the subject of this research paper is to analyze the factors of international distribution from the aspect of international business strategy of SMEs. The research conducted covered various factors related to international distribution strategies such as the ability to deliver international goods quickly and continuously, the established adequate international distribution network, the ability to respond quickly to international partners orders and the effective management of international distributors or agents. The survey was conducted in 50 companies that export various types of products on the territory of the Republic of Serbia. The results of the regression analysis indicate that an adequate distribution network has an impact on sales volume and foreign market share, so that we can conclude that the proper selection of an appropriate distribution network can contribute to enhancing the export potential of the company.
\end{abstract}

Keywords: international distribution, export, distribution channels, small and medium enterprises, international business strategy, Serbia.

JEL classification: $L 1, M 1, M 3$

\footnotetext{
*bojanvapa@gmail.com
} 


\title{
UPRAVLJANJE KANALIMA MEĐUNARODNE DISTRIBUCIJE U STRATEGIJI MEĐUNARODNOG POSLOVANJA MALIH I SREDNJIH PREDUZEĆA
}

\begin{abstract}
Sažetak: Preduzeća koja baziraju svoju strategiju zasnovanu na indirektnom ulasku na strana tržišta moraju da donesu odluku o izboru adekvatnih međunarodnih kanala distribucije. Dobro implementiran sistem međunarodne distribucije u izvozno orijentisanim preduzećima može da doprinese unapređenju konkurentnosti ovih preduzeća, kao i boljem pozicioniranju njihovih proizvoda na inostranim tržištima. Predmet istraživanja rada obuhvata analizu faktora međunarodne distribucije sa aspekta strategije međunarodnog poslovanja MSP-a. U okviru sprovedenog istraživanja obuhvaćeni su različiti faktori u vezi sa strategijom međunarodne distribucije, kao što su sposobnost brze i kontinuirane isporuke, uspostavljena adekvatna mreža distribucije, sposobnost brze reakcije na narudžbe inopartnera $i$ efektivno upravljanje inodistributerima ili agentima. Istraživanje je sprovedeno u 50 preduzeća koja se bave izvozom različitih vrsta proizvoda na teritoriji Republike Srbije. Rezultati regresione analize ukazuju da uspostavljena adekvatna mreža međunarodne distribucije utiče na obim prodaje $i$ udeo na stranom tržištu, tako da možemo da zaključimo da pravilan izbor odgovarajuće mreže međunarodne distribucije može da doprinese jačanju izvoznog potencijala preduzeća.
\end{abstract}

Ključne reči: međunarodna distribucija, izvoz, kanali distribucije, mala i srednja preduzeća, strategija međunarodnog poslovanja, Srbija

\section{INTRODUCTION}

When focusing on the international market, a company is faced with decisions on how to enter a foreign market, through which channels and how to manage marketing logistics (Menkinoski, Risteska and Ilieska, 2000). Terminologically, the word "channel" comes from the French language, and in international marketing activities it indicates the path that a product travels from the place of production to the point of consumption. Most producers who participate in the international business transactions are not directly engaged in the direct sale of their products in the international market. As a result, there is a need for having intermediaries between producers and end consumers. In bridging the existing geographical gap between producers and consumers in the international market, international distribution channels represent an effective tool (Grubor, 2008). International distribution is an activity that overcomes all the differences in space and time between production in one country and the use of their products abroad (Previšić and Ozretić Došen, 2000). Grubor (2005) confirms that the modern business practice and the long-term stability of international distribution 
channels is of great importance for the success, although it emphasizes that there are also situations when adjusting distribution channels to new market relations is necessary. Research findings by Vapa Tankosić, Ignjatijević and Gardašević (2015) showed that factors affecting the difficult positioning of Serbian SMEs in the foreign market, primarily in the EU market, in addition to the complexity of export documentation, were poor organization of the export department, inadequate design products, high transportation costs, and inadequate promotion of businesses in export markets. The authors ŽunićKovačević, Vapa-Tankosić and Lazić (2016) have performed a survey on export activities of SMEs in Croatia and Serbia in order to compare the qualitative export performance factors related to the level of entrance to the European single market. High costs of export financing, lack of effective government programs for exporters, strong international competition and the complexity of documents for export are proven to be the most significant barriers for SMEs in Croatia and Serbia. The results have confirmed that SMEs in Serbia do not possess an export strategy, and export sales are often a result of sporadic contact from foreign markets. However, both Serbian and Croatian SMEs exporters consider themselves able to cope with competition from the EU, in terms of quality, price and design. With an aim to further explore one important factor of international business the scope of this paper is to analyze the impact of international distribution factors on export performance of small and mediumsized enterprises in the Republic of Serbia (with special emphasis on their sales volume on the foreign market, foreign market share and export profitability).

\section{LITERATURE OVERVIEW}

In recent years, the organization of international distribution methods has expanded with new modalities, primarily related to the abandonment of distribution for the mass market and the transition to individualization of the international distribution system, with three basic profiles of organizing distribution channels (Jović, 2007):

- traditional forms - distributor network, agents, brokers, retail network, etc.

- cooperation forms - franchising, licenses, strategic retail sales analysis, etc.

- interactive or individualized forms - sales via computer (on the Internet), direct marketing, etc.

Choosing the optimal distribution channel abroad is one of the most difficult and responsible tasks for an exporter. Wrong decisions in the field of international distribution can jeopardize the entire export activity of a company. In the complex conditions of a rapidly changing international environment, it is irrational to expect that a company will design and implement different 
distribution strategies for each foreign market, but nevertheless the enterprise should take into account the specificities of each individual foreign market and its environment (Previšić and Ozretić Došen, 2000). It takes several years to create a proper distribution channel system and it is not easy to change (Rakita, 2005). When deciding on distribution channels, a company also looks at the extent to which it wants to engage in international business, ie. degree of market coverage. In view of this, a company may opt for:

- intensive distribution - products are marketed through a large number of international marketing agents and outlets,

- selective distribution - products are marketed in geographically defined parts of the market and in retail outlets where the highest profit is expected,

- exclusive distribution - products are marketed through one form of distribution channel for each selected target market (Lancaster and Massingham, 1997).

There are a lot of intermediaries between producers and consumers in export marketing. Distance affects greater complexity of distribution and logistics, cultural differences affect the mismatch of motivation and goals of foreign partners and market distance affects difficult communication between foreign partners. These are the factors that make it difficult to manage relationships with foreign intermediaries. Therefore, information on intermediaries plays a key role in minimizing risk in the international market (Nijssen, Douglas and Calis, 1999).

There are two categories of members that need to be included in the sales channel system in order for export and distribution to a foreign market to be feasible and realistic:

- manufacturer and intermediaries - carrying members of the distribution channel,

- insurance companies, freight forwarders, banks and carriers complementary distribution members (Rakita, 2012).

Supporting members have an active role, as to initiating activities, controlling ownership of the goods and taking responsibility towards the end consumers, while the complementary members provide services such as smooth distribution, assuming full or partial responsibility towards the supporting members of the physical security channel for the goods (products) or creating the necessary financial assumptions for export and distribution. 
Defining international distribution channels should be done in the most efficient way to satisfy the following linked entities (Salai and Božidarević, 1997):

- $\quad$ business distribution - which includes channel selection, degree of market coverage, marketing intermediaries, etc.

- $\quad$ physical distribution - covering the activities of inventory, storage, transport, packaging, etc.

Grubor (2005) uses the term international logistics, which in addition to activities related to physical distribution also includes activities that are focused on material management, such as managing relationship with customers and suppliers. The experience of modern international business practice shows that the logistics costs range from $10 \%$ to $25 \%$ of the total cost of shipping the products, which gives companies with a higher degree of international orientation a number of alternative options for improving the quality in the functioning of international logistics. Three cost groups can be distinguished within distribution channels:

- initial costs - include the cost of locating and setting up distribution channels (travel, negotiation costs, channel selection, etc.),

- maintenance costs - include the cost of sales force of the company, sales manager, transportation, sales, control, advertising and broker profit margin and

- logistics costs - include the cost of transporting, storing, splitting large consignments into smaller and the cost of customs documentation.

When multinationals introduce their products to a foreign market for the first time they want to work with local distributors who know the local market. However, disagreements often arise. Multinational companies can complain that the local distributor does not apply the company policy, does not invest in the development and improvement of packaging, does not provide enough information, etc. On the other hand, local distributors complain of insufficient corporate support, confusing company policies and impossible goals to reach. For this reason, it is necessary for the company to select good distributors, invest in them and set acceptable goals (Arnold, 2000). If the exporter provides support to a foreign broker and builds a long-term and quality relationship, together they can achieve sustainable competitive positions in the international market (Piercy, Katsikeas and Cravens, 1997). It is necessary for the company to also determine the terms and responsibilities of all members participating in the distribution channel, such as (Kotler, 1988):

- a pricing policy that requires the manufacturer to establish a price list and rebates- the manufacturer must be sure that the intermediaries find the rebates fair and sufficient, 
- terms of sale relating to payment terms and the manufacturer's warranty, with manufacturers being able to extend warranties relating to damaged goods or to price drops - a price drop is used to encourage distributors to buy larger quantities of goods (products),

- territorial rights - which are important because brokers need to know if the manufacturer will give rights to other brokers in the area, and would also like to receive large credits for all sales in their area, regardless of how they are sold,

- services and responsibilities must be carefully specified, especially with franchised agencies, so that there are no omissions that would affect sales.

In the international relationships between companies and consumers, a major barrier is market distance, ie. geographical, economic, socio-cultural and political-legal specificities of the international market (O'Grady and Lane, 1996). When analyzing the role and importance of distribution channels and its members, it is necessary to analyze the relationships, role and importance of foreign consumers, since an exporter with a high level of competence in the area of creating relationships with consumers and intermediaries abroad achieves better export results and a sustainable competitive advantage (Kaleka, 2011). Individualization of the international distribution system implies a more immediate approach to consumers, with marketing research being an indispensable information base on the needs of the observed consumers (Salai, and Božidarević, 1997, p.313). By gathering information on consumers and potential consumers and their needs, marketing research enables an adequate selection of the profiles for organizing international distribution channels (Grubor, 2005).

Intermediaries play a very important role in the formation of a consumer database. They are usually in contact with the final consumers and provide information about them. On the basis of these data, differentiation of consumers is made according to their specific needs on the basis of which the company creates offers of products and services (Mitić, 2014). The role of intermediaries in the analysis of these market differences is very important and helps to maintain long distribution channels that are a major obstacle to developing larger-scale retailing in developing countries (Kotler and Keler, 2006). Intermediaries in international distribution channels perform many relevant functions such as (Kotler, 2000):

- gathering information about consumers (current and potential), competitors and factors of the marketing environment,

- reaching agreement on payment terms and prices, which enables efficient change of ownership and possession of goods (products), 
- developing and disseminating persuasive communication to stimulate purchase,

- creating funds for financing innovations at different levels of marketing channels,

- placing orders with manufacturers,

- assuming the risk of international product distribution,

- ensuring payment to customers through banks and other financial institutions,

- monitoring current transfer of ownership from one owner (business) to another (business or individual) and

- ensuring successful goods storage.

Given that distribution involves the continuous placement of goods by manufacturers, both domestically and internationally, it is also necessary to create distribution contracts in order to legally regulate the responsibilities of the parties (Divljak, 2010). However, the complex legal nature and structure of international distribution agreements, often cause problems and ambiguities during its implementation in international business transactions, leading to disputes, as well as economic losses (Perovic, 2010). In order to avoid and overcome these problems it is necessary to build a quality relationship based on trust, commitment and satisfaction between exporters and intermediaries (Skarmeas, Katsikeas, Spyropoulou and Salehi-Sangari, 2008). When there is mutual trust between business partners, they are ready to commit themselves to further enhancing relationships leading to greater satisfaction (Morgan and Shelby, 1994).

The quality of relations with intermediaries is directly related to export performance. A recent scale has been developed in the literature to measure the quality of the relationship between intermediaries and exporters, comprising four dimensions (Lages, Lages and Lages, 2005):

- information to be exchanged - based on the frequency of partner meetings to discuss strategic issues and exchange market and other confidential information,

- quality of communication - the existence of continuous formal and informal communication,

- long-term orientation - the desire to preserve long-term relationships,

- satisfaction with established relationships - an emotional state that results from an assessment of an existing relationship with a partner, which implies satisfaction with the partner, their cooperation and alignment of the results with expectations. 


\section{METHODOLOGY}

The survey was conducted in 50 SMEs that export various types of products on the territory of the Republic of Serbia. In order to maximize the representativeness of the sample, the survey covers companies whose business is based on a diverse and wide range, ranging from the production and export of alcoholic beverages, agricultural machinery, cables and boilers, electrical appliances, furniture, wardrobes, telecommunications equipment, which contributes to the quality of research. The survey was conducted over a period of six months, from January to June 2016. In accordance with the previously defined hypotheses, as well as in accordance with the subject and objectives of the research, an appropriate theoretical and methodological framework was set in the paper. The survey instrument was a questionnaire. The questionnaire was created solely for the purpose of this research (Likert scale 1-5 was used). Obtained survey data were analyzed by regression analysis with the level of significance set at 0.05. Data were processed in the SPSS statistical package. The hypothesis of the paper is as follows:

International distribution factors identified for the purpose of this research, such as the ability to deliver goods promptly and continuously, an adequately established distribution network, the ability to respond quickly to international partners orders, and the effective management of international distributors or agents has a significant impact on improving export performance companies.

\section{RESULTS}

Based on the descriptive statistical indicators shown in Table 1 for the total score on the distribution questionnaire, it is possible to assess the extent to which companies consider a particular claim to be true. According to the results shown in Table 1, it is concluded that the majority of companies (62\%) believe that their ability to respond quickly to international partners orders is fully present, while $60 \%$ of companies state that ability to deliver goods promptly and continuously is fully present. A much smaller percentage of companies (38\%) believe that the activity of an established active international distribution network is fully present in their business (while $32 \%$ of enterprises say that an adequate distribution network is present in the medium degree, and $30 \%$ of the surveyed companies think that it is not present at all). It is evident that some companies lack effective management of international distributors or agents because as many as $32 \%$ of companies say that this feature is not present at all in their business, and $52 \%$ of surveyed companies consider it to be present in the medium degree, with just $16 \%$ of surveyed companies believe that it is fully present. 
40 | MANAGEMENT OF THE INTERNATIONAL DISTRIBUTION CHANNELS IN THE SMES INTERNATIONAL BUSINESS STRATEGY

Table 1

Descriptive statistical indicators for international distribution

\begin{tabular}{|l|c|c|c|c|c|c|}
\hline \multirow{2}{*}{\begin{tabular}{l}
\multirow{2}{*}{$\begin{array}{c}\text { International } \\
\text { distribution }\end{array}$} \\
\cline { 2 - 7 }
\end{tabular}} & \multicolumn{2}{|c|}{ Not present } & \multicolumn{2}{c|}{$\begin{array}{c}\text { Present in the } \\
\text { medium degree }\end{array}$} & \multicolumn{2}{c|}{ Fully present } \\
\cline { 2 - 7 } $\begin{array}{l}\text { Ability to deliver } \\
\text { goods quickly and } \\
\text { continuously }\end{array}$ & 2 & 4 & 18 & 36 & 30 & 60 \\
\hline $\begin{array}{l}\text { Adequate } \\
\text { international } \\
\text { distribution network } \\
\text { established }\end{array}$ & 15 & 30 & 16 & 32 & 19 & 38 \\
\hline $\begin{array}{l}\text { Ability to respond } \\
\text { quickly to } \\
\text { international } \\
\text { partners orders }\end{array}$ & 2 & 4 & 17 & 34 & 31 & 62 \\
\hline $\begin{array}{l}\text { Effective } \\
\text { management of } \\
\text { international } \\
\text { distributors or } \\
\text { agents }\end{array}$ & 16 & 32 & 26 & 52 & 8 & 16 \\
\hline
\end{tabular}

Note. Calculated by the authors.

As a part of this research, the impact of international distribution on the export performance of a company - volume of sales in a foreign market, share in a foreign market and exports profitability - was further analysed by regression analysis. For this purpose, regression analyses were performed in which the factors of export performance of the company were criterion variables, while the set of predictors constituted the factors of international distribution.

The results of the regression analysis in which sales volume was included as a criterion variable and a set of predictor variables representing international distribution factors indicate that the model proved to be significant $(\mathrm{F}=2.982$, $\mathrm{p} \leq .05$ ) and explained $13,9 \%$ of the variance (Adjusted $\mathrm{R}^{2}=.139$ ) of the dependent variable (international sales volume). 
Table 2

Regression analysis: international distribution - international sales volume criterion

\begin{tabular}{|l|c|c|c|c|c|c|c|c|}
\hline & $\begin{array}{c}\text { Sum of } \\
\text { squares }\end{array}$ & $\begin{array}{c}\text { Degrees } \\
\text { of } \\
\text { freedom }\end{array}$ & $\begin{array}{c}\text { Mean } \\
\text { Square }\end{array}$ & $\mathbf{F}$ & $\begin{array}{c}\text { Signifi } \\
\text { cance } \\
\text { level }\end{array}$ & $\mathbf{R}$ & $\mathbf{R}^{\mathbf{2}}$ & $\begin{array}{c}\text { Adjusted } \\
\text { R-squared }\end{array}$ \\
\hline Regression & 4.950 & 4 & 1.237 & $\begin{array}{c}2.9 \\
82\end{array}$ & .029 & $\begin{array}{c}.45 \\
8\end{array}$ & .210 & .139 \\
\hline
\end{tabular}

Note. Calculated by the authors.

Table 3

International distribution factors as predictors of international sales volume

\begin{tabular}{|l|c|c|c|c|c|}
\hline \multirow{2}{*}{ Predictors } & \multicolumn{2}{|c|}{$\begin{array}{c}\text { Unstandardized } \\
\text { coefficients }\end{array}$} & $\begin{array}{c}\text { Standardized } \\
\text { coefficients }\end{array}$ & \multirow{2}{*}{ T } & $\begin{array}{c}\text { Significance } \\
\text { level }\end{array}$ \\
\cline { 2 - 5 } & $B$ & $\begin{array}{c}\text { Standard } \\
\text { error }\end{array}$ & Beta & & .024 \\
\hline Constant & 1.177 & .502 & & 2.344 & .255 \\
\hline $\begin{array}{l}\text { Ability to deliver } \\
\text { goods quickly and } \\
\text { continuously }\end{array}$ & .214 & .186 & .178 & 1.153 & .25 \\
\hline $\begin{array}{l}\text { Adequate } \\
\text { international } \\
\text { distribution network } \\
\text { established }\end{array}$ & $\mathbf{. 3 0 5}$ & $\mathbf{. 1 4 4}$ & $\mathbf{. 3 6 4}$ & $\mathbf{2 . 1 2 5}$ & $\mathbf{. 0 3 9}$ \\
\hline $\begin{array}{l}\text { Ability to respond } \\
\text { quickly to international } \\
\text { partners orders }\end{array}$ & -.071 & .187 & -.059 & -.381 & .705 \\
\hline $\begin{array}{l}\text { Effective management } \\
\text { of international } \\
\text { distributors or agents }\end{array}$ & .046 & .170 & .045 & .269 & .789 \\
\hline
\end{tabular}

Note. Calculated by the authors.

An adequate international distribution network is proven to be the only significant predictor in the Table $3(\beta=.364, \mathrm{p} \leq .05)$. Based on the results obtained, it can be concluded that an adequate international distribution network contributes to international sales volume, while the ability to deliver fast and continuous delivery, quick reactions to international partners orders and effective management of international distributors have not been proven to be predictors of the international sales volume. 
42 | MANAGEMENT OF THE INTERNATIONAL DISTRIBUTION CHANNELS IN THE SMES INTERNATIONAL BUSINESS STRATEGY

Table 4

Regression analysis: international distribution - foreign market share

\begin{tabular}{|c|c|c|c|c|c|c|c|c|}
\hline & 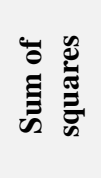 & 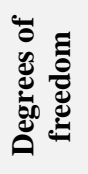 & 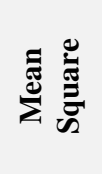 & 工s & 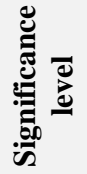 & $\simeq$ & $\approx$ & 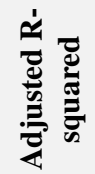 \\
\hline Regression & 5.979 & 4 & 1.495 & 2.800 & .037 & .446 & .199 & .128 \\
\hline
\end{tabular}

Note. Calculated by the authors.

The results of the regression analysis in which the share in the foreign market is included as a criterion variable and the set of predictor variables representing the factors of international distribution indicate that the model proved to be significant $(\mathrm{F}=2.800, \mathrm{p} \leq .05)$ and explained $12.8 \%$ of the variance (adjusted $\mathrm{R}^{2}$ $=.128$ ) of the dependent variable (foreign market share).

Table 5

International distribution factors as predictors of foreign market share

\begin{tabular}{|l|c|c|c|c|c|}
\hline \multirow{2}{*}{ Predictors } & \multicolumn{2}{|c|}{$\begin{array}{c}\text { Unstandardized } \\
\text { coefficients }\end{array}$} & $\begin{array}{c}\text { Standardized } \\
\text { coefficients }\end{array}$ & T & $\begin{array}{c}\text { Significance } \\
\text { level }\end{array}$ \\
\cline { 2 - 6 } & $B$ & $\begin{array}{c}\text { Standard } \\
\text { error }\end{array}$ & Beta & .081 \\
\hline Constant & 1.015 & .570 & & .162 & .872 \\
\hline $\begin{array}{l}\text { Ability to deliver } \\
\text { goods quickly and } \\
\text { continuously }\end{array}$ & .034 & .210 & .025 & 2.278 & .028 \\
\hline $\begin{array}{l}\text { Adequate } \\
\text { international } \\
\text { distribution } \\
\text { network } \\
\text { established }\end{array}$ & .371 & .163 & .393 & -.067 & .947 \\
\hline $\begin{array}{l}\text { Ability to respond } \\
\text { quickly to } \\
\text { international } \\
\text { partners orders }\end{array}$ & -.014 & .212 & -.010 & .459 & .649 \\
\hline $\begin{array}{l}\text { Effective } \\
\text { management of } \\
\text { international } \\
\text { distributors or } \\
\text { agents }\end{array}$ & .089 & .193 & & & \\
\hline
\end{tabular}

Note. Calculated by the authors. 
An adequate international distribution network is proven to be the only significant predictor $(\beta=.393, \mathrm{p} \leq .05)$, in the Table 5. Based on the results obtained, it can be concluded that an adequate international distribution network contributes to international sales volume, while the ability to deliver fast and continuous delivery, quick reactions to international partners' orders and effective management of international distributors have not been proven to be predictors of the foreign market share.

Table 6

Regression analysis: international distribution - exports profitability

\begin{tabular}{|c|c|c|c|c|c|c|c|c|}
\hline & 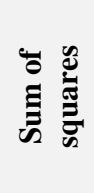 & 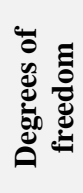 & 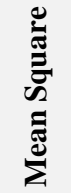 & $\sqrt{x}$ & 遶 & $\simeq$ & $\approx$ & 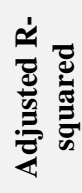 \\
\hline Regression & 3.326 & 4 & .832 & 2.331 & .070 & .414 & .172 & .098 \\
\hline
\end{tabular}

Note. Calculated by the authors.

The results of the regression analysis in which the exports profitability is included as a criterion variable and the set of predictor variables representing the factors of international distribution indicate that the model did not prove to be significant $(\mathrm{F}=2.331, \mathrm{p} \geq .05)$. This result suggests that there is no proven statistical influence of international distribution on exports profitability.

\section{CONCLUSION}

Based on the results of the research, we can conclude that most companies state that they are fully capable of responding quickly to orders from foreign partners and that the companies also claim that their ability as ragards fast and continuous delivery of goods to international distributors is fully present. The largest number of companies in this survey estimated that effective management of international distributors or agents is fully present or present in the medium degree in their business (68\%), while almost one-third of the sample companies claim that effective management of international distributors or agents is not present in their business at all. The obtained data show that most companies consider that they have an adequate international distribution network (70\%) and one third of the sample companies claim that an adequate international distribution network is not present in their business at all. These results point to an underdeveloped relationship with international distributors and agents, although in theoretical terms this relationship has been found to be extremely important for successful export. The speed of response to international partner orders is certainly influenced by the choice of distribution channel, and 

INTERNATIONAL BUSINESS STRATEGY

therefore the claims of companies regarding the speed of reaction to international partner orders contradict the statements regarding the presence and establishment of an adequate distribution network. Grubor (2008) confirms that without the proper functioning of international distribution channels, even the perfect product with the right price and even promotion cannot be exchanged in the international market.

The hypothesis of the paper was that international distribution factors ie. fast and continuous international goods delivery capability, adequately established international distribution network, ability to respond quickly to international market orders and efficient management of international distributors and agents has a significant impact on the international sales volume of SMEs in the foreign market, foreign market share and export profitability, has been partially confirmed. The results of the regression analysis indicate that the established adequate international distribution network has a significant influence on the volume of foreign sales and foreign market share. To this end, we can conclude that strategic management of the international distribution network can improve the competitive position of SMEs in the foreign market, and thus contribute to a greater volume of foreign sales and sales share in the international market. Studying distribution, as an element of the international marketing, can reveal the specificity and complexity of international distribution, which is in turn conditioned by the characteristics of different markets, and the specific geographical location of consumers, which results in the companies search for adequate solutions related to distribution channels. The differences between distribution channels in individual countries are significant and the company can not easily apply the same distribution model in different countries. Understanding the process of creating, implementing and maintaining an international distribution, as a part of the international business strategy, can help researchers study further factors involved in realization of international transactions, as well as companies in adequately pricing and successfully promoting their products in the international market.

\section{REFERENCES}

Arnold, D. (2000). Seven rules of international distribution. Harvard Business Review, 78(6), 13-137.

Divljak, D. (2010). Ugovor o međunarodnoj distribuciji. Pravni život, 59(11), 345-354.

Grubor, A. (2005). Informacije međunarodnih marketing istraživanja u funkciji kanala distribucije. Anali Ekonomskog fakulteta u Subotici, 14, 133-144.

Grubor, A. (2008). Marketing istraživanja: integralni deo međunarodnog marketing programa. Subotica: Ekonomski fakultet. 
Jović, M. (2007). Međunarodni marketing. Beograd: IntermaNet.

Kaleka, A. (2011). When exporting manufacturers compete on the basic of service: Resources and marketing capabilities driving service advantage and performance. Journal of International Marketing, 19(1), 40-58.

Kotler, P. (1988). Upravljanje marketingom 1: analiza, planiranje i kontrola. Zagreb: Informator.

Kotler, P. (2000). Marketing management: The Millennium Edition. Upper Saddle River: Prentice-Hall.

Kotler, P., \& Keler, K. L. (2006). Marketing menadžment. Beograd: Datastatus.

Lages, C., Lages, C. R., \& Lages, L. F. (2005). The RELQUAL scale: a measaure of relationship in export market ventures. Journal of Business Research, 58(8), 1040-1048.

Lancaster, G., \& Massingham, L. (1997). Menadžment u marketingu. Beograd: Grmeč.

Menkinoski, G., Risteska, A., \& Ilieska, K. (2000). Distribucija kao instrument međunarodnog marketing programa. Strategijski menadžment, 4(4), 1012.

Mitić, S. (2014). Upravljanje izvozom: nematerijalni i marketinški aspekti konkurentnosti. Beograd: Ekonomski fakultet, Centar za izdavačku delatnost.

Morgan, R. M., \& Shelby, D. H. (1994). The Commitment-trust theory of relationship marketing. Journal of Marketing, 58(3), 20-38.

Nijssen, J. E., Douglas, P. S., \& Calis, G. (1999). Gathering and using information for the selection of trading partners. European Journal of Marketing, 33(1-2), 143-162.

O'Grady, S., \& Lane, H. (1996). The psychic distance paradox. Jornal of International Business Studies, 27(2), 309-333.

Perović, J. (2010). Sporne odredbe ugovora o međunarodnoj distribuciji. Pravo i privreda, 47(4-6), 359-376.

Piercy, N., Katsikeas, S. C., \& Cravens, W. D. (1997). Examining the role of buyer-seller relationship in export performance. Journal of World Business, 32(1), 73-86.

Previšić, J., \& Ozretić Došen, Đ. (2000). Osnove međunarodnog marketinga. Zagreb: Masmedija. 
46 | MANAGEMENT OF THE INTERNATIONAL DISTRIBUTION CHANNELS IN THE SMES INTERNATIONAL BUSINESS STRATEGY

Racela, O. C., Chaikittisilpa, C., \& Thoumrungroje, A. (2007). Market orientation, international business relationships and perceived export performance. International Marketing Review, 24(2), 144-163.

Rakita, B. (2012). Međunarodni marketing: od lokalne do globalne perspektive. Beograd: Ekonomski fakultet.

Rakita, B., \& Mitić, S. (2012). Networking and clustering as contemporary strategies of business internationalization. In From Global Crisis to Economic Growth. Which Way to Take? (47-78). Belgrade: Faculty of Economics.

Rakić, B. (2004). Međunarodni marketing. Beograd: Megatrend univerzitet primenjenih nauka.

Salai, S., \& Božidarević, D. (1997). Marketing istraživanje: informaciona osnova marketing menadžmenta. Beograd: Savremena administracija.

Skarmeas, D., Katsikeas, S. C., Spyropoulou, S., \& Salehi-Sangari, E. (2008). Market and supplier characteristics driving distributor relationship quality in international marketing channels of industrial products. Industrial Marketing Management, 37(1), 23-36.

Žunić-Kovačević, N., Vapa-Tankosić, J., \& Lazić, B. (2016). The mechanism of SMEs internationalization towards the EU single market perspective. In European Union Future Perspectives: Innovation, Entrepreneurship and Economic Policy (43-59). Pula: Juraj Dobrila University of Pula.

Vapa -Tankosić, J., Ignjatijević, S., \& Gardašević, J. (2015). Analysis of export performance factors of enterprises from the Republic of Serbia in the process of European integration. Teme, 39(4), 1257-1276.

Vapa-Tankosić J., \& Vapa, B. (2017). The effect of product development and innovation on SMEs export performance. In Innovation, ICT and Education for the next generation (154-171). Novi Sad: Faculty of Economics and Engineering Management.

Delivered: 08.09.2019.

Accepted: 05.12.2019. 